\title{
Effect of cow cleanliness in different housing systems on somatic cell count in milk
}

\author{
Wojciech Neja, Mariusz Bogucki, Małgorzata Jankowska, Anna Sawa \\ University of Science and Technology in Bydgoszcz, Faculty of Animal Breeding and Biology, \\ Department of Cattle Breeding and Animal Feeding, Bydgoszcz, Poland
}

Received February 28, 2015

Accepted November 10, 2015

\begin{abstract}
The aim of the study was to analyse the effect of the housing system (tie-stall vs free-stall) on cow cleanliness, and the effect of the degree of cow dirtiness on the milk somatic cell count. Over $33 \%$ of the cows were found to be clean, with more of them in the free-stall barn. Analysis of the cleanliness of body parts showed that the highest hygiene level was characteristic of the udders and underbelly (scores of 1 for $47 \%$ and $56 \%$ of the cows, respectively). In the free-stall barn, there were over twice as many cows with clean udders $(58 \%)$ and almost twice as few cows with very dirty udders. Regardless of the housing system, the degree of udder dirtiness created differences $(P \leq 0.01)$ in the natural log somatic cell count. The natural log somatic cell count increased from 11.54 to 12.37 on average with increased dirtiness of the udder. Greater differences in the cytological quality of milk were found in cows housed in the free-stall system. When analysing the effect of overall dirtiness of the cows and the body parts on the percentage of SCC classes, it was found that highest quality milk $(<200000$ somatic cells $/ \mathrm{ml}$ ) was produced by clean cows $(71.52 \%)$. The proportion of cows with subclinical and clinical mastitis was found to increase with decreasing cleanliness of the udder, especially in the free-stall system. Overall, the proportion of cows with clinical mastitis increased from $2.51 \%$ (clean cows) to $14.29 \%$ (dirty cows).
\end{abstract}

Bovines, body cleanliness, milk quality

Recent years in Poland have seen a marked increase in the cows' milk yield (Polish Federation of Cattle Breeders and Dairy Farmers 2013) as well as improvements in their welfare, health and housing conditions. However, because the increased performance is paralleled by poorer health, shorter length of productive life and lower technological and qualitative indicators of the milk obtained (Choromańska et al. 2014), the search is still on for factors that improve the quality of raw milk (Szyndler and Kaczor 1998; Winnicki et al. 2003). These factors include cow hygiene, understood as dirtiness of different body areas (Szyndler and Kaczor 1998; Hughes 2001; Schreiner and Ruegg 2002; Zurbrigg et al. 2005; Ellis et al. 2007; Nigel et al. 2007; Bogucki et al. 2010; Hauge et al. 2012). The available studies suggest that the degree of cattle cleanliness can be assessed on a three- (beef cattle) (Hauge et al. 2012), four- (Winnicki and Walczak 1991; San'Anna and Paranhos da Costa 2011) or five-point scale (Hauge et al. 2012). Regardless of the method, the most frequently assessed body parts are those particularly exposed to dirt, i.e. legs, flanks, underbelly and udder.

Studies in Norway (Hauge et al. 2012) suggest that the main contributing factors for animal cleanliness are high indoor humidity, type of animal (heifer, cow, bull calf), housing system (free-stall and tie-stall), faecal consistency, and failure to clean the cows during the year. Sant' Anna and Paranhos da Costa (2011) report from other authors that most studies on cow hygiene determined from animal cleanliness were conducted in free-stall barns.

Address for correspondence:

Wojciech Neja

Department of Cattle Breeding and Animal Feeding

Faculty of Animal Breeding and Biology

University of Science and Technology in Bydgoszcz

ul. Mazowiecka 28, 85-084 Bydgoszcz, Poland 
The aim of the study was to analyse the effect of the housing system (tie-stall vs. freestall) on cow cleanliness and the effect of the degree of cow dirtiness on the milk somatic cell count.

\section{Materials and Methods}

The study was conducted on two farms between May 2013 and June 2014. Cows were kept on litter in the tiestall (farm A) and free-stall (farm B) systems.

Dirtiness of the different body areas (udder, right hind leg, left hind leg, underbelly) was evaluated on the test day once a month according to the procedure of Winnicki and Walczak (1991). Dirtiness was scored on a 4-point scale: 1 - clean, 2 - slightly dirty, 3 - dirty, 4 - very dirty. In addition, overall dirtiness scores were calculated for every cow as a mean of the scores for body area dirtiness. This served as a basis for grouping the animals into the following classes: 1 - clean (1.00-1.75 points), 2 - slightly dirty (1.76-2.50 points), 3 - dirty (2.51-3.25 points), 4 - very dirty (3.26-4.00 points).

The dirtiness score points totalled 2,367 (905 in the tie-stall and 1,462 in the free-stall system). The results for the milk somatic cell count (SCC) were derived from RW2 reports in the SYMLEK system. Because SCC shows high variation and is not normally distributed, the data were transformed to the natural logarithm scale (LNSCC).

The $\chi^{2}$ independence test (14) was used to analyse the frequency of clean, slightly dirty, dirty and very dirty cows, as well as the frequency of dirt in different body areas in both housing systems. Analysis of variance (GLM procedure) (14) was used to evaluate the effect of:

- the housing system on the overall cow dirtiness score, dirtiness of different body areas (udder, hind right leg, hind left leg, underbelly) and LNSCC;

- the overall cow dirtiness score and dirtiness of different body areas (udder, hind right leg, hind left leg, underbelly) on LNSCC.

Significant differences were determined using Scheffe test.

The $\chi^{2}$ independence test (18) was used to analyse the percentage of milk samples indicative of particular udder health condition on the test day, depending on dirtiness of the udder, hind right leg, hind left leg and underbelly, and on the overall cow dirtiness score. In order to determine udder health, milk samples were classified using our modified version of the method reported by Renner (1975): 1 - good udder health; $\leq 200000$ somatic cells per ml milk, 2 - threatened udder health, 200,001-400,000; 3 - subclinical changes 400,001-1,000,000; and 4 - clinical changes, $>1,000,000$ somatic cells per $\mathrm{ml}$ milk. Udder health classes are hereafter referred to as SCC classes.

\section{Results}

Over $33 \%$ of the cows were clean, with more clean cows found in the free-stall barn $(38.58 \%)$ (Table 1). Regardless of the housing system, almost half of the observed cows $(48.54 \%)$ were classified as slightly dirty $(58 \%$ in the tie-stall barn and $43 \%$ in the freestall barn). The frequency of very dirty cows was low and ranged from $1 \%$ (tie-stall barn) to $3 \%$ (free-stall barn). Analysis of the cleanliness of different body parts showed that the highest hygiene level was characteristic of the udders and underbelly (scores of 1 for $47 \%$ and $56 \%$ of the cows, respectively). It is worth noting that a high proportion of the cows $(81 \%)$ with clean underbelly was found in the tie-stall barn. In the free-stall barn, there were over twice as many cows with clean udders (58\%) and almost twice as few cows with very dirty udders.

The proportion of cows with very dirty underbelly was low $(0.55 \%)$ in the tie-stall system and high $(7.32 \%)$ in the free-stall system. About $17 \%$ of the cows had clean hind legs (right and left), with a much higher proportion (about 22\%) in the free-stall barn compared to the tie-stall barn (8-10\% of the cows).

When analysing the effect of the housing system on the overall cow dirtiness score, it was found that loose-housed cows were cleaner $(P \leq 0.01)$ than tethered cows (Table 2$)$. Except the udder, the scores for dirtiness of different body parts were lower for cows from the free-stall system. Likewise, LNSCC was lower for the free-stall (11.69) compared to the tie-stall system (11.76). Regardless of the barn type, the lowest scores were noted for udder (1.23 tie- stall barn, 1.90 free-stall barn) and underbelly (2.05 and 1.95, respectively), which shows that these body parts were the cleanest.

Regardless of the housing system, the degree of udder dirtiness created differences $(P \leq 0.01)$ in the LNSCC value (Table 3$)$. The LNSCC increased from 11.54 to 12.37 on 
average with increased dirtiness of the udder. Greater differences in the cytological quality of milk were observed in cows housed in the free-stall system (LNSCC higher by 1.01). the LNSCC increased with the increasing dirtiness of hind legs and the underbelly, but this tendency was non-significant.

Table 1. Frequency of cows classified as clean, slightly dirty, dirty and very dirty in the analysed housing systems.

\begin{tabular}{|c|c|c|c|c|c|}
\hline \multirow{2}{*}{ Item } & \multirow{2}{*}{ Housing system } & \multicolumn{4}{|c|}{ Proportion (\%) of dirtiness classes } \\
\hline & & 1 & 2 & 3 & 4 \\
\hline Total cows dirtiness & Tie-stall & 25.75 & 57.58 & 15.69 & 0.88 \\
\hline \multirow[t]{2}{*}{$\chi^{2}=68.84^{x x}$} & Free-stall & 38.58 & 42.89 & 15.25 & 3.28 \\
\hline & Total & 33.67 & 48.54 & 15.42 & 2.37 \\
\hline Udder & Tie-stall & 28.62 & 45.19 & 19.34 & 6.85 \\
\hline \multirow{2}{*}{$\chi^{2}=211.37^{\mathrm{xx}}$} & Free-stall & 58.34 & 29.41 & 8.62 & 3.63 \\
\hline & Total & 46.98 & 35.45 & 12.72 & 4.86 \\
\hline Right hind leg & Tie-stall & 9.72 & 47.29 & 30.39 & 12.60 \\
\hline \multirow[t]{2}{*}{$\chi^{2}=79.15^{\mathrm{xx}}$} & Free-stall & 22.44 & 46.72 & 22.44 & 8.41 \\
\hline & Total & 17.57 & 46.94 & 25.48 & 10.01 \\
\hline Left hind leg & Tie-stall & 7.85 & 48.62 & 32.15 & 11.38 \\
\hline \multirow[t]{2}{*}{$\chi^{2}=102.83^{x x}$} & Free-stall & 22.37 & 46.58 & 22.50 & 8.55 \\
\hline & Total & 16.81 & 47.36 & 26.19 & 9.63 \\
\hline Underbelly & Tie-stall & 81.33 & 15.14 & 2.90 & 0.55 \\
\hline \multirow[t]{2}{*}{$\chi^{2}=429.32^{\mathrm{xx}}$} & Free-stall & 40.70 & 35.84 & 16.14 & 7.32 \\
\hline & Total & 56.23 & 27.93 & 11.11 & 4.73 \\
\hline
\end{tabular}

xx - significance at $P \leq 0.01$

Table 2. Effect of the housing system on the overall cow dirtiness score, dirtiness of body parts, and LNSCC.

\begin{tabular}{lcc}
\hline \multirow{2}{*}{ Item } & \multicolumn{2}{c}{ Housing system } \\
\cline { 2 - 3 } & Tie-stall & Free-stall \\
\hline Total dirtiness score (pts.) & $2.04^{\mathrm{A}}$ & $1.57^{\mathrm{A}}$ \\
Udder (pts.) & $1.23^{\mathrm{A}}$ & $1.90^{\mathrm{A}}$ \\
Right hind leg (pts.) & $2.47^{\mathrm{A}}$ & $2.17^{\mathrm{A}}$ \\
Left hind leg (pts.) & $2.46^{\mathrm{A}}$ & $2.16^{\mathrm{A}}$ \\
Underbelly (pts.) & $2.05^{\mathrm{A}}$ & $1.95^{\mathrm{A}}$ \\
LNSCC & 11.76 & 11.69 \\
\hline
\end{tabular}

A - Means within lines followed by the same superscript differ significantly at $P \leq 0.01$

When analysing the effect of overall dirtiness of the cows and the body parts on the percentage of SCC classes, it was found that highest quality milk $(<200000 \mathrm{SCC} / \mathrm{ml})$ was produced by clean cows $(71.52 \%)$ (Table 4$)$. More favourable results were noted for the tie-stall barn, where the proportion of such cows was $75.54 \%$. In both housing systems, the cleanest cows produced the largest proportion of milk samples with $<200000 \mathrm{SCC} / \mathrm{ml}$. At the same time, the percentage of such samples slightly decreased with increasing dirtiness of the cows. Of concern is the increasing proportion of cows with subclinical and clinical mastitis, which occurred with the decreasing cleanliness of the udder, especially in the 
free-stall barn. Overall, the proportion of cows with clinical mastitis increased from $2.51 \%$ (clean cows) to $14.29 \%$ (dirty cows).

Regardless of the housing system, the hind legs were most often determined to be slightly dirty, as was the case with the udder in the tie-stall barn. In turn, the udders of loose-housed cows and the underbelly from both barn types were most often scored as clean. The proportion of clinical mastitis was found to increase with decreasing cleanliness of the underbelly, especially in the free-stall barn.

Table 3. Effect of the overall cow dirtiness score and dirtiness of body parts (udder, right hind leg, left hind leg, underbelly) on LNSCC.

\begin{tabular}{|c|c|c|c|c|}
\hline \multirow{3}{*}{ Item } & & \multicolumn{2}{|c|}{ Housing system } & \multirow{3}{*}{ Total } \\
\hline & & Tie-stall & Free-stall & \\
\hline & & LNSCC & LNSCC & \\
\hline \multirow{4}{*}{ Total dirtiness score (pts.) } & 1 & 11.70 & 11.57 & $11.63^{\mathrm{a}}$ \\
\hline & 2 & 11.77 & 11.71 & 11.74 \\
\hline & 3 & 11.82 & 11.86 & 11.84 \\
\hline & 4 & 12.50 & 12.15 & $12.33^{\mathrm{a}}$ \\
\hline \multirow{4}{*}{ Udder (pts.) } & 1 & $11.55^{\mathrm{a}}$ & $11.52^{\mathrm{AB}}$ & $11.54^{\mathrm{ABC}}$ \\
\hline & 2 & 11.76 & $11.75^{\mathrm{CD}}$ & $11.76^{\mathrm{ADE}}$ \\
\hline & 3 & 11.94 & $12.27^{\mathrm{AC}}$ & $12.10^{\mathrm{BD}}$ \\
\hline & 4 & $12.21^{\mathrm{a}}$ & $12.53^{\mathrm{BD}}$ & $12.37^{\mathrm{CE}}$ \\
\hline \multirow{4}{*}{ Right hind leg (pts.) } & 1 & 11.65 & 11.57 & 11.61 \\
\hline & 2 & 11.77 & 11.69 & 11.71 \\
\hline & 3 & 11.81 & 11.79 & 11.80 \\
\hline & 4 & 11.88 & 11.79 & 11.84 \\
\hline \multirow{4}{*}{ Left hind leg (pts.) } & 1 & 11.78 & 11.56 & 11.67 \\
\hline & 2 & 11.73 & 11.69 & 11.71 \\
\hline & 3 & 11.78 & 11.78 & 11.78 \\
\hline & 4 & 11.84 & 11.78 & 11.81 \\
\hline \multirow{4}{*}{ Underbelly (pts.) } & 1 & 11.77 & 11.66 & 11.72 \\
\hline & 2 & 11.64 & 11.65 & 11.65 \\
\hline & 3 & 12.17 & 11.75 & 11.96 \\
\hline & 4 & 11.94 & 11.97 & 11.93 \\
\hline
\end{tabular}

A - Means within columns followed by the same superscript differ significantly at $P \leq 0.01$

a - Means within columns followed by the same superscript differ significantly at $P \leq 0.05$

\section{Discussion}

According to Hultgren and Bergsten (2001), dairy cow hygiene can be used to determine cow welfare as it provides information about the quality of life of the animals and the level of farm equipment. The fact that we found over $82 \%$ of the cows to be clean or slightly dirty indicates that the herds under analysis showed high levels of hygiene. Sant'Anna and Paranhos da Costa (2011) reported that during the whole year more than half of the cows received regular cleanliness scores for the body parts, $55.62 \%$ of which were classified as very clean and clean, and only $9.76 \%$ as dirty and very dirty.

The superior udder cleanliness found in the free stall was probably associated with easier access to the udder in the milking parlour and better (more comfortable) position of the milker during teat and udder cleaning. Barłowska et al. (2012) suggest that raw milk of high microbiological quality is obtained on farms that use modern milking systems, i.e. milking parlours. 
The results concerning the effect of the housing system on the cleanliness of the hind legs are consistent with Ruegg (2006), who also showed loose-housed cows to be characterized by higher cleanliness of the legs compared to those housed in tie stalls.

In our study we found the lowest scores for the udder and underbelly, regardless of the housing system. These findings are in agreement with the earlier results of Bogucki et al. (2010). Szyndler and Kaczor (1998) reported the mean udder score in a medium-sized stall to be 1.83 , which was equivalent to slight dirtiness. Higher levels of udder dirtiness were reported by Mucha et al. (2003), where udder score averaged 2.9 (dirty udders).

Table 4. Proportion of SCC classes depending on overall dirtiness of the cow and its body parts.

\begin{tabular}{|c|c|c|c|c|c|c|c|}
\hline \multirow{2}{*}{ Item } & & \multirow{2}{*}{$\begin{array}{l}\text { Housing } \\
\text { system }\end{array}$} & \multirow{2}{*}{$\begin{array}{c}\text { No. of } \\
\text { observations }\end{array}$} & \multicolumn{4}{|c|}{ Proportion $(\%)$ of SCC classes } \\
\hline & & & & 1 & 2 & 3 & 4 \\
\hline \multirow{12}{*}{ Total dirtiness score (pts.) } & 1 & \multirow{4}{*}{$\begin{array}{l}\text { Tie-stall } \\
\chi^{2}=15.03\end{array}$} & 233 & 75.54 & 13.30 & 7.70 & 3.43 \\
\hline & 2 & & 522 & 70.50 & 15.33 & 9.00 & 5.17 \\
\hline & 3 & & 142 & 73.94 & 7.75 & 11.97 & 6.24 \\
\hline & 4 & & 8 & 62.50 & 0.00 & 12.50 & 25.00 \\
\hline & 1 & \multirow{4}{*}{$\begin{array}{l}\text { Free-stall } \\
\chi^{2}=34.24^{\mathrm{xx}}\end{array}$} & 564 & 69.86 & 9.33 & 8.69 & 2.13 \\
\hline & 2 & & 627 & 68.42 & 14.67 & 10.69 & 6.22 \\
\hline & 3 & & 223 & 63.23 & 15.25 & 13.00 & 8.52 \\
\hline & 4 & & 48 & 54.17 & 14.58 & 18.75 & 12.5 \\
\hline & 1 & \multirow{4}{*}{$\begin{array}{l}\text { Total } \\
\chi^{2}=38.94^{\mathrm{xx}}\end{array}$} & 797 & 71.52 & 17.57 & 8.41 & 2.51 \\
\hline & 2 & & 1149 & 69.36 & 17.97 & 9.92 & 5.74 \\
\hline & 3 & & 365 & 67.40 & 12.33 & 12.60 & 7.67 \\
\hline & 4 & & 56 & 55.36 & 12.55 & 17.86 & 14.29 \\
\hline \multirow{12}{*}{ Udder (pts.) } & 1 & \multirow{4}{*}{$\begin{array}{l}\text { Tie-stall } \\
\chi^{2}=28.11^{\mathrm{xx}}\end{array}$} & 259 & 79.92 & 11.20 & 6.56 & 2.32 \\
\hline & 2 & & 409 & 72.37 & 14.67 & 7.33 & 5.62 \\
\hline & 3 & & 175 & 62.71 & 14.86 & 13.71 & 5.71 \\
\hline & 4 & & 62 & 58.06 & 11.29 & 19.35 & 11.29 \\
\hline & 1 & \multirow{4}{*}{$\begin{array}{l}\text { Free-stall } \\
\chi^{2}=112.13^{\mathrm{xx}}\end{array}$} & 853 & 72.92 & 18.05 & 6.80 & 2.23 \\
\hline & 2 & & 430 & 66.74 & 14.65 & 10.93 & 7.67 \\
\hline & 3 & & 126 & 48.41 & 15.08 & 22.22 & 14.29 \\
\hline & 4 & & 53 & 37.74 & 11.32 & 39.62 & 11.32 \\
\hline & 1 & \multirow{4}{*}{$\begin{array}{l}\text { Total } \\
\chi^{2}=114.57^{\mathrm{xx}}\end{array}$} & 1112 & 74.55 & 16.46 & 6.74 & 2.25 \\
\hline & 2 & & 839 & 69.49 & 14.66 & 9.18 & 6.67 \\
\hline & 3 & & 301 & 58.47 & 14.95 & 17.28 & 9.30 \\
\hline & 4 & & 115 & 48.70 & 11.30 & 28.70 & 11.30 \\
\hline \multirow{12}{*}{ Right hind leg (pts.) } & 1 & \multirow{4}{*}{$\begin{array}{l}\text { Tie-stall } \\
\chi^{2}=10.90\end{array}$} & 88 & 78.41 & 11.36 & 6.82 & 3.41 \\
\hline & 2 & & 428 & 72.66 & 15.42 & 8.18 & 3.74 \\
\hline & 3 & & 275 & 69.82 & 12.73 & 10.18 & 7.27 \\
\hline & 4 & & 114 & 71.93 & 9.65 & 12.28 & 6.14 \\
\hline & 1 & \multirow{4}{*}{$\begin{array}{l}\text { Free-stall } \\
\chi^{2}=18.07^{x}\end{array}$} & 328 & 70.43 & 18.29 & 8.84 & 2.44 \\
\hline & 2 & & 683 & 68.23 & 16.11 & 10.69 & 4.98 \\
\hline & 3 & & 328 & 64.33 & 17.68 & 10.06 & 7.98 \\
\hline & 4 & & 123 & 66.67 & 11.38 & 15.45 & 6.50 \\
\hline & 1 & \multirow{4}{*}{$\begin{array}{l}\text { Total } \\
\chi^{2}=24.25^{\mathrm{xx}}\end{array}$} & 416 & 72.12 & 16.83 & 8.41 & 2.64 \\
\hline & 2 & & 1111 & 69.94 & 15.84 & 9.72 & 4.50 \\
\hline & 3 & & 603 & 66.83 & 15.42 & 10.12 & 7.67 \\
\hline & 4 & & 237 & 69.20 & 10.55 & 13.92 & 6.33 \\
\hline
\end{tabular}


Table 4. Proportion of SCC classes depending on overall dirtiness of the cow and its body parts.

\begin{tabular}{|c|c|c|c|c|c|c|c|}
\hline \multirow{2}{*}{ Item } & & \multirow{2}{*}{$\begin{array}{l}\text { Housing } \\
\text { system }\end{array}$} & \multirow{2}{*}{$\begin{array}{c}\text { No. of } \\
\text { observations }\end{array}$} & \multicolumn{4}{|c|}{ Proportion (\%) of SCC classes } \\
\hline & & & & 1 & 2 & 3 & 4 \\
\hline \multirow{12}{*}{ Left hind leg (pts.) } & 1 & \multirow{4}{*}{$\begin{array}{l}\text { Tie-stall } \\
\chi^{2}=17.63^{x}\end{array}$} & 71 & 71.83 & 12.68 & 14.08 & 1.41 \\
\hline & 2 & & 440 & 73.18 & 15.68 & 6.82 & 4.32 \\
\hline & 3 & & 291 & 70.45 & 12.71 & 9.97 & 6.87 \\
\hline & 4 & & 103 & 73.79 & 6.80 & 13.57 & 5.83 \\
\hline & 1 & \multirow{4}{*}{$\begin{array}{l}\text { Free-stall } \\
\chi^{2}=18.30^{\mathrm{x}}\end{array}$} & 327 & 70.64 & 18.35 & 8.56 & 2.45 \\
\hline & 2 & & 681 & 68.14 & 16.15 & 10.72 & 4.99 \\
\hline & 3 & & 329 & 64.13 & 17.63 & 10.33 & 7.90 \\
\hline & 4 & & 125 & 67.20 & 11.20 & 15.20 & 6.40 \\
\hline & 1 & \multirow{4}{*}{$\begin{array}{l}\text { Total } \\
\chi^{2}=27.80^{\mathrm{xx}}\end{array}$} & 398 & 70.85 & 17.34 & 9.55 & 2.26 \\
\hline & 2 & & 1121 & 70.12 & 15.97 & 9.19 & 4.73 \\
\hline & 3 & & 620 & 67.50 & 15.32 & 10.16 & 7.42 \\
\hline & 4 & & 228 & 70.18 & 9.21 & 14.47 & 6.14 \\
\hline \multirow{12}{*}{ Underbelly (pts.) } & 1 & \multirow{4}{*}{$\begin{array}{l}\text { Tie-stall } \\
\chi^{2}=13.55\end{array}$} & 736 & 71.60 & 14.54 & 9.10 & 4.76 \\
\hline & 2 & & 137 & 78.83 & 8.03 & 7.30 & 5.84 \\
\hline & 3 & & 27 & 59.26 & 14.81 & 14.81 & 11.11 \\
\hline & 4 & & 5 & 60.00 & 0.00 & 40.00 & 0.00 \\
\hline & 1 & \multirow{4}{*}{$\begin{array}{l}\text { Free-stall } \\
\chi^{2}=19.10^{\mathrm{xx}}\end{array}$} & 595 & 67.06 & 18.82 & 10.92 & 3.19 \\
\hline & 2 & & 524 & 69.47 & 15.08 & 10.50 & 4.96 \\
\hline & 3 & & 236 & 67.37 & 15.68 & 8.90 & 8.05 \\
\hline & 4 & & 107 & 63.55 & 13.08 & 12.15 & 11.21 \\
\hline & 1 & \multirow{4}{*}{$\begin{array}{l}\text { Total } \\
\chi^{2}=18.57^{\mathrm{xx}}\end{array}$} & 1331 & 69.57 & 16.45 & 9.92 & 4.06 \\
\hline & 2 & & 661 & 71.41 & 13.62 & 9.83 & 5.14 \\
\hline & 3 & & 263 & 66.54 & 15.59 & 9.51 & 8.37 \\
\hline & 4 & & 112 & 63.39 & 12.50 & 13.39 & 10.71 \\
\hline
\end{tabular}

xx - significance at $P \leq 0.0$

The increase in the natural log somatic cell count, which increased with increasing udder dirtiness, was consistent with an earlier study by Bogucki et al. (2010), in which LNSCC increased from 11.81 for clean udders to 12.61 for udders classified as very dirty.

According to Abe (1999), teats and udder become dirty from the legs, which may explain the fact that in our study LNSCC increased with the increasing dirtiness of the hind legs and the underbelly.

Our findings, which show a relationship $(P \leq 0.01)$ between cow cleanliness scores and milk quality, agree with research conducted in Great Britain (Ellis et al. 2007). The milk of cows with greater udder cleanliness was found to contain fewer somatic cells. The low level of cow hygiene, as reported by Barkema et al. (1998), Schreiner and Ruegg (2002), Rueg (2006) and Ellis et al. (2007) may be associated with the increased incidence of mastitis, which is one of the biggest concerns for dairy farmers. Mastitis has an adverse effect not only on herd productivity but also on the welfare of animals (Philpot and Nickerson 1991). According to Hauge et al. (2001), keeping animals clean in dairy herds is the basis for a hygienic production of milk. At the same time, Philips (2002) maintains that pathogenic agents, such as the increasing incidence of Escherichia coli, are best dealt with by improving the level of hygiene on the farms.

In conclusion, over $82 \%$ of the cows were characterized by clean or slightly dirty body parts, which shows high hygiene levels in the analysed herds. The cleanest body parts, 
regardless of the housing system, were the udder and underbelly, but the proportion of cows whose body parts were classified as clean was over twice as high in the free-stall compared to the tie-stall system. The cytological quality of milk deteriorated the most with udder dirtiness, especially in the free-stall barn.

\section{References}

Abe N 1999: The deeper the "mud", the dirtier the udder. Hoard's Dairyman 144: 439

Barkema HW, Schukken H, Lam TJGM, Beiboer ML, Benedictus G, and Brand A 1998: Management practices associated with low, medium, and high somatic cell counts in bulk milk. J Dairy Sci Vol 81: 1917-1927

Barłowska J, Jarosińska A, Wolanciuk A, Kędzierska-Matysek M 2012: The quality of market milk obtained from farms, employing diverse systems of milking. Rocz Nauk PTZ 8: 31-38

Bogucki M, Sawa A, Krężel-Czopek S, Neja W, Sass $Ł$ 2010: Effect of degree of dirtiness of cows on milk quality. Acta Sci Pol Zoot 9: 3-8

Choromańska D, Brzozowska A, Oprządek J 2014: Effect of number of lactation on physical activity of dairy cows. Prz Hod 6: 13-15

Ellis KA, Innocent GT, Mihm M, Cripps P, Mclean WG, Howard CV, and Grove-White D 2007: Dairy cow cleanliness and milk quality on organic and conventional farms in the UK. J Dairy Res 74: 302-310

Hauge SJ, Kielland C, Ringdal G, Skjerve E, Nafstad O 2012: Factors associated with cattle cleanliness on Norwegian dairy farms. J Dairy Sci 95: 2485-2496

Hughes J. 2001: A system for assessing cow cleanliness. In Pract 23: 517-524

Hultgren J, Bergsten C 2001: Effects of a rubber-slatted flooring system on cleanliness and foot health in tied dairy cows. Prev Vet Med 52: 75-89

Mucha $Ł$, Bogucki M, Jankowska M 2003: Housing and milking systems as compared to cow productivity and behaviour. Proc. of the Conference "Animal nutrition vs. health and current issues in veterinary hygiene and prevention”. September 4-7, 2003 Ciechocinek, pp. 86-88

Nigel BC, Douglas JR 2007: A tool box for assessing cow, udder and teat hygiene. Annual meeting of the NMC, University of Wisconsin-Madison

Performance recording results of dairy breed cattle in 2013 - tables. www.pfhb.pl

Philips C 2002: Cattle behavior and welfare. Willey-Blackwell, New Jersey, 274 p.

Philpot WN, Nickerson SC 1991: Mastitis: Counter Attack. Babson Bros., Naperville, IL.

Renner E 1975: Investigations on some parameters of milk for the detection of subclinical mastitis. Proc Semin Mast Cont, IDF Doc

Ruegg PL 2006: The role of hygiene in efficient milking. WCDS Adv Dairy Techn 18: 285-293

Sant'Anna AC, Paranhos da Costa MJR 2011: The relationship between dairy cow hygiene and somatic cell count in milk. J Dairy Sci 94: 3835-3844

SAS Institute Inc. 2013. SAS/STATR 9.3 User's Guide. Cary, NC: SAS Institute Inc.

Schreiner DA, Ruegg PL 2002: Effects of tail docking on milk quality and cow cleanliness. J Dairy Sci 85 : 2503-2511

Schreiner DA, Ruegg PL 2003: Relationship between udder and leg hygiene scores and subclinical mastitis. J Dairy Sci 86: 3460-346

Szyndler J, Kaczor A 1998: Hygiene of dairy cows kept in different types of tie stalls. National Research Institute of Animal Production, Krakow, pp. 81-90

Winnicki S, Nawrocki L, Werbiński R, Myczko A 2003: Living conditions of cows vs. milk quality. $9^{\text {th }}$ International Symposium, IBMER, Warszawa, pp. 123-125

Winnicki S, Walczak H 1991: Study on cow living conditions in stalls with different dimensions and equipment. Zesz Nauk Prz Hod 3: 194-197

Zurbrigg K, Kelton D, Anderson N, Millman S 2005: Tie-stall design and its relationship to lameness, injury, and cleanliness on 317 Ontario Dairy Farms. J Dairy Sci 88: 3201-3210 